\title{
Effect of Biostimulants on Yield and Quality of Cherry Tomatoes Grown in Fertile and Stressed Soils
}

\author{
Metin Turan \\ Department of Genetics and Bioengineering, Yeditepe University, Atasehir, \\ 34755, Istanbul, Turkey \\ Ertan Yildirim and Melek Ekinci \\ Department of Horticulture, Atatürk University, 25240, Erzurum, Turkey
}

\author{
Sanem Argin \\ Department of Agricultural Trade and Management, Yeditepe University, \\ Atasehir, 34755, Istanbul, Turkey
}

Additional index words. humic substance, mineral content, plant growth, Solanum lycopersicum var. cerasiforme

\begin{abstract}
Plant biostimulants are microorganisms (PGPR) and/or products obtained from different organic substances that positively affect plant growth and efficiency and reduce the negative effects of abiotic challenges. Effects of biostimulants on the plant growth, yield, mineral content, antioxidant enzyme activity, $\mathrm{H}_{2} \mathrm{O}_{2}$, malondialdehyde (MDA), sucrose, and proline contents of cherry tomato (Solanum lycopersicum var. cerasiforme L.) grown in soils with two different characteristics were investigated during a pot study under greenhouse conditions. Soil I was a fertile routinely vegetable-cultivated soil. Soil II had high salinity, high $\mathrm{CaCO}_{3}$ content, and low organic matter content. Commercial biostimulant products Powhumus ${ }^{\circledR}$ (PH), Huminbio Microsense Seed ${ }^{\circledR}$ (SC), Huminbio Microsense Bio ${ }^{\circledR}$ (RE), and Fulvagra ${ }^{\circledR}$ (FU) were used as seed coatings and/or drench solutions. All biostimulant treatments improved the plant growth and yield compared with the control in both soils. All biostimulant applications were more effective in soil II than in soil I. RE was the most effective application for mineral content in soil I, whereas FU was the most effective in soil II. Antioxidant activity, $\mathrm{H}_{2} \mathrm{O}_{2}$, MDA, and proline contents were decreased in both soils when biostimulants were used compared with the control. Peroxide (POD) activity was greater with SC1 in soil II. The RE treatment increased the sucrose content in soil II. In conclusion, single and combined use of high-purity fulvic acid and PGPR had positive effects on the growth of cherry tomato in fertile soil and under stressed conditions.
\end{abstract}

Biostimulants are organically based plantpromoting substances/microorganisms applied to soil to increase the nutrient uptake, stimulate plant growth, increase tolerance to abiotic and biotic challenges, and improve product quality. Protein hydrolysates, seaweed extracts, chitosan, humic acid (HA), fulvic acid (FA), phosphite, arbuscular mycorrhizal fungi, and/or PGPR are used as biostimulants to enhance plant production (Battacharyya et al., 2015; Bradáčová et al., 2016; Canellas et al., 2015; Cimrin et al., 2010; Colla et al., 2015; Gómez-Merino and

Received for publication 6 Nov. 2020. Accepted for publication 19 Nov. 2020.

Published online 5 March 2021

We are grateful to Humintech $\mathrm{GmbH}$ for support for this study.

M.T. and E.Y. are the corresponding authors. E-mail: m_turan25@hotmail.com or ertanyil@atauni. edu.tr.

This is an open access article distributed under the CC BY-NC-ND license (https://creativecommons. org/licenses/by-nc-nd/4.0/).
FAs are mixtures of weak, water-soluble, aliphatic, and aromatic organic acids. They have a molecular weight between 1000 and $10,000 \mathrm{Da}$ and smaller molecules than those of HA. Because of the relatively small size of FA molecules, they can easily penetrate plant roots, stems, and leaves. Fulvic acids have twice the oxygen content of HA and are the main components of high-quality fertilizers (Pettit, 2008).

PGPR are naturally occurring soil bacteria that colonize plant roots and promote plant growth through phosphate solubility, siderophore production, biological nitrogen fixation, 1-aminocyclopropane-1-carboxylate deaminase (ACC) production, and phytohormone production (Bhattacharyya and Jha, 2012; Saharan and Nehra, 2011). Inoculation of plants with PGPR can increase seed germination, seedlings, growth, plant height $(\mathrm{PH})$, shoot weight, nutrient content, bloom period, chlorophyll content, nodulation in legumes, yield, and production (Ekinci et al., 2014; Saharan and Nehra, 2011; Turan et al., 2014; Yildirim et al., 2015). Alcaligenes, Arthrobacter, Azospirillum, Azotobacter, Bacillus, Burkholderia, Enterobacter, Klebsiella, Pseudomonas, and Serratia belong to the PGPR family and effectively promote plant growth and development (Glick, 1995; Kloepper et al., 1989).

Low and high temperatures, salinity, drought, heavy metal toxicity, and nutrient deficiency are abiotic factors that can reduce plant production (Bray et al., 2000; Sahin et al., 2015, 2018; Zhu, 2016). Plants with low tolerance to stress consume more water and fertilizer, thus leading to the depletion of natural resources (Zhu, 2016). The protective effects of humic substances on plants against stress result in increased tolerance, yield, and crop quality (Akinci, 2017; Canellas et al., 2015; Mora et al., 2014).

Studies showed that biostimulants can be used to alleviate the damage caused by synthetic fertilizers (Posmyk and Szafrańska, 2016; Van Oosten et al., 2017) that are used to increase the yield and quality of different vegetable crops grown in the fields and greenhouses. This study was performed to determine the effects of the single use and combined use of high-purity FA and PGPR on the growth, yield, and quality of cherry tomatoes grown in soils with different characteristics.

\section{Materials and Methods}

2015; Chen and Aviad, 1990, MacCarthy, 2001; Yildirim, 2007). Humic substances, which are sources of organic carbon, are formed by chemical and biological conversions of animals and plants (Canellas et al., 2015). Some low-molecular-weight compounds in humic substances increase the cell membrane permeability when they are taken-up by plants. Therefore, humic substances increase the nutrient uptake in a manner similar to that of hormones (Chen and Aviad, 1990; Nardi et al., 2002). Moreover, humic substances have positive effects on plant growth under abiotic challenge that can be used to help promote sustainable production (Canellas et al., 2015).
Cherry tomato (cv. Bright F1) were grown in pots containing soils with two different compositions (Table 1) in the greenhouse of Atatürk University, Erzurum, during Spring 2019. Four different commercial products, namely, $\mathrm{PH}, \mathrm{SC}, \mathrm{RE}$, and FU, were used as biostimulants (Table 2). Two types of treatment were applied: 1) seeds were only coated with the biostimulant solution (PH1 and SC1) or 2) seeds were drenched with biostimulant drench solutions after coating once per week from day 14 (a total of six times during the study for 
each sample; PH2, SC2, RE, and FU). NPK was applied in all treatments, including the control.

The coating of seeds was achieved as follows: seeds were soaked in biostimulant solutions $\left(333 \mathrm{~g} \cdot \mathrm{L}^{-1}\right)$ for $3 \mathrm{~h}$ at $20^{\circ} \mathrm{C}$; then, the liquid was drained off and seeds were airdried for $1 \mathrm{~d}$ at $24 \pm 2{ }^{\circ} \mathrm{C}$. After seeds were sown into multicell trays filled with peat, seedling trays were placed on benches in the greenhouse. Developing seedlings were kept under natural daylight (approximate day/ night temperatures of $30 / 16{ }^{\circ} \mathrm{C}$ for $16 / 8 \mathrm{~h}$ and $50 \%$ relative humidity). Seedlings were irrigated every day. No fertilizer was applied to the developing seedlings.

Seedlings at the three true leaf stage were transplanted to 8 -L plastic pots containing soil I and soil II (Table 1). Soil I was a fertile, routinely vegetable-cultivated soil and soil II had a high $\mathrm{CaCO}_{3}$ content, low organic matter content, and high salinity.

Table 1. Properties and composition of soils used in the study.

\begin{tabular}{lrr}
\hline Property/content & \multicolumn{1}{c}{ Soil I } & \multicolumn{1}{c}{ Soil II } \\
\hline $\mathrm{pH}(1: 2.5 \mathrm{~s} / \mathrm{w})$ & $7.10 \pm 0.28$ & $7.90 \pm 0.14$ \\
Organic matter $(\%)$ & $1.40 \pm 0.10$ & $0.10 \pm 0.11$ \\
Total N (\%) & $0.12 \pm 0.06$ & $0.096 \pm 0.007$ \\
$\mathrm{CaCO}_{3}(\%)$ & $0.88 \pm 0.70$ & $12.20 \pm 1.10$ \\
$\mathrm{~K}\left(\mathrm{cmol} \cdot \mathrm{kg}^{-1}\right)$ & $2.25 \pm 0.21$ & $2.10 \pm 0.15$ \\
$\mathrm{Ca}\left(\mathrm{cmol} \cdot \mathrm{kg}^{-1}\right)$ & $12.85 \pm 1.22$ & $14.00 \pm 1.10$ \\
$\mathrm{Mg}\left(\mathrm{cmol} \cdot \mathrm{kg}^{-1}\right)$ & $2.83 \pm 0.10$ & $2.30 \pm 0.09$ \\
$\mathrm{Na}\left(\mathrm{cmol} \cdot \mathrm{kg}^{-1}\right)$ & $0.74 \pm 0.06$ & $4.50 \pm 0.04$ \\
Effective P $\left(\mathrm{mg} \cdot \mathrm{kg}^{-1}\right)$ & $3.10 \pm 0.20$ & $4.10 \pm 0.20$ \\
Electrical conductivity $\left(\mathrm{dS} \cdot \mathrm{m}^{-1}\right)$ & $0.510 \pm 0.21$ & $2.860 \pm 0.21$ \\
Sand $(\%)$ & $34.30 \pm 1.12$ & $36.40 \pm 1.12$ \\
Silt $(\%)$ & $35.50 \pm 0.95$ & $25.50 \pm 0.95$ \\
Clay $(\%)$ & $30.20 \pm 1.40$ & $38.10 \pm 1.40$ \\
Texture & Loamy & Clay loamy \\
\hline
\end{tabular}

A randomized factorial experimental design was used. Tests were conducted in triplicate and three plants were used per replicate (a total of 126 pots were analyzed).

Soil was irrigated when the field capacity of pots reached $60 \%$. Fertilization and other cultural practices of Maynard and Hochmuth (2007) were applied. The chlorophyll reading value, fruit weight (FW), fruit width (FWi), fruit diameter (FD), and fruit dry matter were determined during cultivation. Experiments were ended $90 \mathrm{~d}$ after transplanting by cutting the plants at the soil ground level, and $\mathrm{PH}$, stem diameter (SD), number of leaves, vitamin C (VC) content, total soluble solids (TSS) were determined. The VC content and TSS were determined using an ascorbic acid test kit (ASC-1; Hach Company, Loveland, $\mathrm{CO}$ ) and a portable refractometer (PR32 Palette; Atago Co. Ltd., Tokyo, Japan), respectively.

Shoots and roots were separated for further analysis. Samples were dried in a forced air oven at $68^{\circ} \mathrm{C}$ for $48 \mathrm{~h}$ to obtain the shoot dry weight (SDW) and root dry weight (RDW). Fresh leaf samples were kept at $-80{ }^{\circ} \mathrm{C}$ for analysis.

The mineral contents of tomato leaves, roots, and fruits were determined using an

Table 2. Biostimulant treatments.

\begin{tabular}{|c|c|c|c|c|}
\hline \multirow[b]{2}{*}{$\begin{array}{l}\text { Commercial biostimulant } \\
\text { product applied }\end{array}$} & \multirow[b]{2}{*}{$\begin{array}{l}\text { Content and physical properties of the } \\
\text { biostimulant product }\end{array}$} & \multicolumn{3}{|c|}{ Treatment $^{\mathrm{z}}$} \\
\hline & & & $\begin{array}{c}\text { Seed coating with } \\
\text { biostimulant solution } \\
\left(333 \mathrm{~g} \cdot \mathrm{L}^{-1}\right)\end{array}$ & $\begin{array}{l}\text { Coated seeds drenched with } \\
\text { biostimulant drench solution } \\
\left(1 \mathrm{~mL} \cdot 200 \mathrm{~mL}^{-1}\right)^{\mathrm{y}}\end{array}$ \\
\hline Powhumus ${ }^{\circledR}$ (Humintech & Content ( $\%$ dry wt): potassium humates: $80 \%$ to $85 \%$ & PH1 & + & - \\
\hline $\begin{array}{l}\text { GMBH, AM Pösenberg 9- } \\
\text { 13, Grevenbroich/ } \\
\text { Germany) }\end{array}$ & $\begin{array}{l}\text { Potassium as } \mathrm{K}_{2} \mathrm{O}: 10 \% \text { to } 12 \% \\
\text { Total organic nitrogen: } 1.0 \% \\
\text { Others: } 2.0 \% \\
\text { Particle size of insoluble constituents: }<100 \mu \mathrm{m} \\
\text { pH: } 9-10\end{array}$ & $\mathrm{PH} 2$ & + & + \\
\hline $\begin{array}{l}\text { Huminbio Microsense Seed } \\
\text { (Huminbio Tarım Ürünleri } \\
\text { AŞ Beşiktaş/İstanbul/ } \\
\text { Turkey) }\end{array}$ & $\begin{array}{l}\text { Content ( } \% \text { dry wt): potassium humates: } 80 \% \text { to } 85 \% \\
\text { Potassium as } \mathrm{K}_{2} \mathrm{O}: 10 \% \text { to } 12 \% \\
\text { Total organic nitrogen: } 1.0 \% \\
\mathrm{ZnO}: 35 \% ; \mathrm{P}: 1 \% \\
\text { Others: } 2.0 \% \\
\text { Microorganisms }\left(1 \times 10^{9} \mathrm{cfu} \cdot \mathrm{mL}^{-1}\right) \text { : } \\
\text { Bacillus megaterium, B. subtilis, B. licheniformis, } \\
\quad \text { Peanibacillus polymyxa, Lactococcus spp. } \\
\text { Indole-3 acetic acid: } 4 \mathrm{~mm} \text { Cytokinin: } 2 \mathrm{~mm} \\
\text { pH: } 9-10\end{array}$ & $\begin{array}{l}\mathrm{SC} 1 \\
\mathrm{SC} 2\end{array}$ & $\begin{array}{l}+ \\
+\end{array}$ & $\begin{array}{l}- \\
+\end{array}$ \\
\hline $\begin{array}{l}\text { Huminbio Microsense Bio }{ }^{\circledR} \\
\text { (Huminbio Tarım Ürünleri } \\
\text { AŞ Beşiktaş/İstanbul/ } \\
\text { Turkey) }\end{array}$ & $\begin{array}{l}\text { Content ( } \% \text { dry wt): potassium humates: } 80 \% \text { to } 85 \% \\
\text { Potassium as } \mathrm{K}_{2} \mathrm{O}: 10 \% \text { to } 12 \% \\
\text { Total organic nitrogen: } 1.0 \% \\
\text { Others: } 2.0 \% \\
\text { Microorganisms }\left(1 \times 10^{9} \mathrm{cfu} \cdot \mathrm{mL}^{-1}\right) \text { : } \\
\text { Azotobacter chroococcum spp., Azospirillum } \\
\quad \text { brasilence } \text { spp., Peanibacillus polymyxa, Bacillus } \\
\text { pumulis, B. megaterium, B. subtilis } \\
\text { pH: } 9-10\end{array}$ & $\mathrm{RE}$ & + & + \\
\hline $\begin{array}{l}\text { Fulvagra }^{\circledR} \text { (Humintech } \\
\text { GMBH, AM Pösenberg } \\
\text { 9-13, Grevenbroich/ } \\
\text { Germany) }\end{array}$ & $\begin{array}{l}\text { Content ( } \% \text { dry wt): } \\
\text { Fulvic acid: } 17 \% \text {, } \\
\text { Humic acid: } 3.0 \% \text {, } \\
\text { Organic substance: } 22 \% \text {; other minerals: } 3.0 \% \\
\text { Others } 2.0 \% \\
\text { Microorganisms }\left(1 \times 10^{9} \mathrm{cfu} \cdot \mathrm{mL}^{-1}\right) \text { : } \\
\text { Azotobacter chroococcum spp., Azospirillum } \\
\quad \text { brasilence } \text { spp., Peanibacillus polymyxa, Bacillus } \\
\text { pumulis, Bacillus megaterium, Bacillus subtilis } \\
\text { pH: } 9-10\end{array}$ & FU & + & + \\
\hline & & Control & - & - \\
\hline
\end{tabular}

${ }_{\mathrm{z}} \mathrm{NPK}$ was applied for all treatments including control.

${ }^{\mathrm{y}}$ Treatment was applied once per week from day 14 (a total of six times during the study). 
inductively coupled plasma spectrophotometer (Optima 2100 DV; Perkin-Elmer, Shelton, CT) (Bremner, 1996; Mertens, 2005a, 2005b). Assays of antioxidant enzyme activity were performed according to the methods of Agarwal and Pandey (2004), Angelini et al. (1990), Gong et al. (2001), and Yordanova et al. (2004). Lipid peroxidation was evaluated by measuring MDA and $\mathrm{H}_{2} \mathrm{O}_{2}$ contents as described in Liu et al. (2014). Sucrose and proline contents were estimated using the methods of $\mathrm{Wu}$ et al. (2011) and Man et al. (2011), respectively.

All data were analyzed using the SPSS version 18.0 (IBM, Armonk, NY). Duncan's multiple range test (DMRT) was used to determine the differences among samples $(P<0.05, P<0.01$, and $P<0.001)$.

\section{Results}

An analysis of variance for biostimulant treatments and soil types was found to be significant for all variables (Tables 3-5). The $\mathrm{PH}, \mathrm{SD}$, leaf number, SDW, and RDW were significantly higher for soil I than for soil II (Fig. 1). However, the chlorophyll reading values (CRVs) were significantly different for soil I and soil II for the applications with Powhumus.

The SC1 treatment was found to be the most effective for PH, SD, SDW, RDW, and CRV of the cherry tomatoes grown in soil I, followed by SC2, RE, and FU applications. However, the FU treatment was found to be more effective in soil II for the same parameters, followed by RE, SC2, and SC1 (Fig. 1). Taller plants and thicker stems were achieved in soil I when the SC2 treatment was applied. The SC2, RE, and FU treatments produced the tallest plants and thickest stems in soil II.
The RE, FU, and SC2 biostimulant treatments most effectively improved the growth in soil II. The maximum SDW was achieved by $\mathrm{SC} 1$ application in soil I, whereas the RDW was higher when SC2 and RE treatments were applied. In soil II, the SDW and RDW were higher for the plants treated with RE and FU (Fig. 1).

The cluster per plant (CPP), fruit number per cluster (FC), cluster weight $(\mathrm{CW}), \mathrm{FW}$, $\mathrm{FD}, \mathrm{FWi}$, fruit yield $(\mathrm{Y})$, fruit dry matter (FDM), TSS, and VC content of cherry tomato were affected by the biostimulant treatments in both soils (Fig. 2). SC1, SC2, and $\mathrm{RE}$ treatments were more effective for CPP and CW in soil I, whereas SC1, RE, and FU treatments resulted in significantly higher numbers in soil II. SC1, SC2, RE, and FU applications were more effective for $\mathrm{FC}$ in both soils. The widest fruits were achieved as a result of $\mathrm{SC} 2, \mathrm{SC} 1, \mathrm{PH} 2, \mathrm{RE}$, and $\mathrm{FU}$ treatments in soil $\mathrm{I}$, and as a result of FU and RE applications in soil II. The highest $\mathrm{Y}$ was obtained with RE and SC2 treatments in soil I, and with FU and RE treatments in soil II. The highest FDM was achieved by RE and SC2 applications in soil I, and by SC2, RE, and SC1 applications in soil II. Although $\mathrm{SC} 1, \mathrm{SC} 2, \mathrm{RE}$, and $\mathrm{FU}$ applications were the most effective for TSS in soil I, only SC1 and SC2 treatments resulted in significantly higher TSS in soil II. The VC content was significantly higher with $\mathrm{SC} 1, \mathrm{SC} 2$, and $\mathrm{RE}$ treatments in soil I, and with $\mathrm{SC} 1, \mathrm{SC} 2, \mathrm{RE}$, and FU in soil II. The results showed that the FU treatment increased the FC, CPP, and the yield per plant in soil II (Fig. 2).

The treatments also affected the mineral content of tomato leaves, fruits, and roots compared with the control (Figs. 3 and 4). Plants in soil I generally had a higher plant nutrient content than those grown in soil II. The RE and FU treatments increased the plant nutrient content in leaves, roots, and fruits in soil I and soil II, respectively, whereas the increase in mineral content in soil I was the highest with RE, SC1, SC2 applications; in soil II, the FU treatment increased the mineral contents of leaves, roots, and fruit compared with other applications.

In soil I, leaf $\mathrm{N}, \mathrm{P}, \mathrm{K}, \mathrm{Ca}, \mathrm{Mg}, \mathrm{Na}, \mathrm{Mn}, \mathrm{Zn}$, $\mathrm{Fe}$, and $\mathrm{Cl}$ contents were highest with the $\mathrm{RE}$ application. However, the lowest values were observed in control plants (Figs. 3 and 4). Root N, P, K, Ca, Mg, Na, Mn, Zn, Fe, and Cl contents were highest with the RE application in soil I, whereas the lowest results were observed in control plants (Figs. 3 and 4). The highest $\mathrm{N}, \mathrm{P}, \mathrm{K}, \mathrm{Mg}, \mathrm{Mn}, \mathrm{Zn}, \mathrm{Fe}$, and $\mathrm{Cl}$ contents in the fruit of cherry tomato were achieved as a result of RE treatment. However, in soil I, the highest $\mathrm{Ca}$ and $\mathrm{Na}$ contents in fruit were obtained with $\mathrm{FU}$ and $\mathrm{SC} 1$ treatments, respectively. The mineral content of the control group was the lowest among all treatments (Figs. 3 and 4).

The mineral contents of leaves, roots, and fruits of cherry tomato grown in soil II were lower than those of grown in soil I. In soil II, the highest leaf, root, and fruit $\mathrm{N}, \mathrm{P}, \mathrm{K}, \mathrm{Ca}$, $\mathrm{Mg}, \mathrm{Na}, \mathrm{Mn}, \mathrm{Zn}$, and $\mathrm{Fe}$ contents were observed in FU-treated plants, whereas the lowest values were observed in the control group (Figs. 3 and 4). However, the highest $\mathrm{Cl}$ contents of leaves, roots, and fruit were achieved with the RE treatment in soil II (Fig. 4).

As can be seen in Fig. 5, the treatments affected the enzyme activity of plant leaves. Activities of catalase (CAT), superoxide (SOD), and POD and the contents of $\mathrm{H}_{2} \mathrm{O}_{2}$,

Table 3. Analysis of variance for the effects of soil, treatments, and the growth $\times$ yield parameters of cherry tomato.

\begin{tabular}{|c|c|c|c|c|c|c|c|c|}
\hline Source & Plant ht & Stem diam & No. of leaves & Shoot dry wt & Root dry wt & Chlorophyll reading value & Vitamin C & TSS \\
\hline Soil & $* * *$ & $* * *$ & $* * *$ & $* * *$ & $* * *$ & $* *$ & $* * *$ & $* * *$ \\
\hline Treatment & $* * *$ & $* * *$ & $* * *$ & $* * *$ & $* * *$ & $* * *$ & $* * *$ & $* * *$ \\
\hline Soil $\times$ treatment & $* * *$ & $* *$ & $* * *$ & $* * *$ & $* * *$ & NS & NS & $*$ \\
\hline Soil & $\begin{array}{l}\text { Cluster wt } \\
* * *\end{array}$ & $\begin{array}{l}\text { Yield } \\
* * *\end{array}$ & $\begin{array}{c}\text { Fruit wt } \\
* * *\end{array}$ & $\begin{array}{c}\text { Fruit width } \\
* * *\end{array}$ & $\begin{array}{l}\text { Fruit diameter } \\
\qquad * * *\end{array}$ & $\begin{array}{c}\text { Fruit dry matter } \\
* * *\end{array}$ & $\underset{* * *}{\text { Clusters/plant }}$ & $\begin{array}{c}\text { Fruit/cluster } \\
* * *\end{array}$ \\
\hline Treatment & $* * *$ & $* * *$ & $* * *$ & $* * *$ & $* * *$ & $* * *$ & $* * *$ & $* * *$ \\
\hline Soil $\times$ treatment & $* *$ & $* * *$ & $* *$ & NS & $* * *$ & $* * *$ & $* * *$ & $*$ \\
\hline
\end{tabular}

TSS $=$ total soluble solids.

NS, * **,***Nonsignificant or significant at $P<0.05,0.01$, or 0.001 , respectively.

Table 4. Analysis of variance for the effects of soil, treatments, and interactions with leaf, root, and fruit mineral contents of cherry tomato.

\begin{tabular}{|c|c|c|c|c|c|c|c|c|c|c|}
\hline Source & $\mathrm{N}$ & $\mathrm{P}$ & $\mathrm{K}$ & $\mathrm{Ca}$ & $\mathrm{Na}$ & $\mathrm{Mg}$ & $\mathrm{Fe}$ & $\mathrm{Cl}$ & $\mathrm{Mn}$ & $\mathrm{Zn}$ \\
\hline & \multicolumn{10}{|c|}{ Leaf } \\
\hline Soil & $* * *$ & $* * *$ & $* * *$ & $* * *$ & $* * *$ & $* * *$ & $* * *$ & $* * *$ & $* * *$ & $* * *$ \\
\hline Treatment & $* * *$ & $* * *$ & $* * *$ & $* * *$ & $* * *$ & $* * *$ & $* * *$ & $* * *$ & $* * *$ & $* * *$ \\
\hline \multirow[t]{2}{*}{ Soil $\times$ treatment } & $* * *$ & $* * *$ & $* * *$ & $* * *$ & $* * *$ & $* * *$ & $* * *$ & $* * *$ & $* * *$ & $* * *$ \\
\hline & \multicolumn{10}{|c|}{ Root } \\
\hline Soil & $* * *$ & $* * *$ & $* * *$ & $* * *$ & $* * *$ & $* * *$ & $* * *$ & $* * *$ & $* * *$ & $* * *$ \\
\hline Treatment & $* * *$ & $* * *$ & $* * *$ & $* * *$ & $* * *$ & $* * *$ & $* * *$ & $* * *$ & $* * *$ & $* * *$ \\
\hline \multirow[t]{2}{*}{ Soil $\times$ treatment } & $* * *$ & $* * *$ & $* * *$ & $* * *$ & $* * *$ & $* * *$ & $* * *$ & $* *$ & $* * *$ & $* * *$ \\
\hline & \multicolumn{10}{|c|}{ Fruit } \\
\hline Soil & $* * *$ & $* * *$ & $* * *$ & $* * *$ & $* * *$ & $* * *$ & $* * *$ & $* * *$ & $* * *$ & $* * *$ \\
\hline Treatment & $* * *$ & $* * *$ & $* * *$ & $* * *$ & $* * *$ & $* * *$ & $* * *$ & $* *$ & $* * *$ & $* * *$ \\
\hline Soil $\times$ treatment & $* * *$ & $* * *$ & $* * *$ & $* * *$ & $* * *$ & $* * *$ & $* * *$ & $*$ & $* * *$ & $* * *$ \\
\hline
\end{tabular}

*,**,***Significant at $P<0.05,0.01$, or $P<0.001$, respectively. 
MDA, proline, and sucrose were higher in plants in soil II than in those grown in soil I. The CAT, SOD, and POD activities of plants were decreased due to treatments with humic substances in soil I compared with the control. The highest value was observed in control plants in both soils. The POD activity was increased due to the SC1 treatment in soil II. The lowest CAT and POD activities were observed with the SC2 treatment. The lowest SOD activity was observed with the RE treatment in soil I and with the FU, RE, and FU treatments in soil II (Fig. 5).

The $\mathrm{H}_{2} \mathrm{O}_{2}$, MDA, sucrose, and proline contents were higher in control plants grown in soil II compared with those grown in soil I. However, treatments with biostimulants resulted in a decrease in soil II contents

Table 5. Analysis of variance for the effects of soil, treatments, and interactions with the activities of CAT, POD, and SOD and the contents of $\mathrm{H}_{2} \mathrm{O}_{2}$, MDA, sucrose, and proline.

\begin{tabular}{llllllll}
\hline Source & $\mathrm{CAT}$ & $\mathrm{POD}$ & $\mathrm{SOD}$ & $\mathrm{H}_{2} \mathrm{O}_{2}$ & $\mathrm{MDA}$ & Sucrose & Proline \\
\hline Soil & $* * *$ & $* * *$ & $* * *$ & $* * *$ & $* * *$ & $* * *$ & $* * *$ \\
Treatment & $* * *$ & $* * *$ & $* * *$ & $* * *$ & $* * *$ & $* * *$ & $* * *$ \\
Soil $\times$ treatment & $* * *$ & $* * *$ & $* * *$ & $* * *$ & $* * *$ & $* * *$ & $* * *$ \\
\hline
\end{tabular}

$\mathrm{CAT}=$ catalase $; \mathrm{POD}=$ peroxide $; \mathrm{SOD}=$ superoxide dismutase $; \mathrm{MDA}=$ malondialdehyde $; \mathrm{H}_{2} \mathrm{O}_{2}=$ hydrogen peroxide.

$* * *$ Significant at $P<0.001$.

except for sucrose. In soil $\mathrm{I}$, the highest $\mathrm{H}_{2}$ $\mathrm{O}_{2}$, proline, and MDA contents were observed in the control plants. The lowest $\mathrm{H}_{2}$ $\mathrm{O}_{2}$ values were observed with the SC2, RE, and FU treatments, whereas the lowest MDA contents were observed with the SC1, SC2, and $\mathrm{RE}$ treatments. In soil II, the lowest $\mathrm{H}_{2}$ $\mathrm{O}_{2}, \mathrm{MDA}$, and proline contents were observed in the plants treated with FU (Fig. 5). The sucrose content of tomato leaves increased due to treatment with humic substances. The highest sucrose contents were observed with the RE treatment in both soils (Fig. 5).

\section{Discussion}

Sustainable soil management is essential for a sustainable food system because $90 \%$ of food production is still dependent on soil.

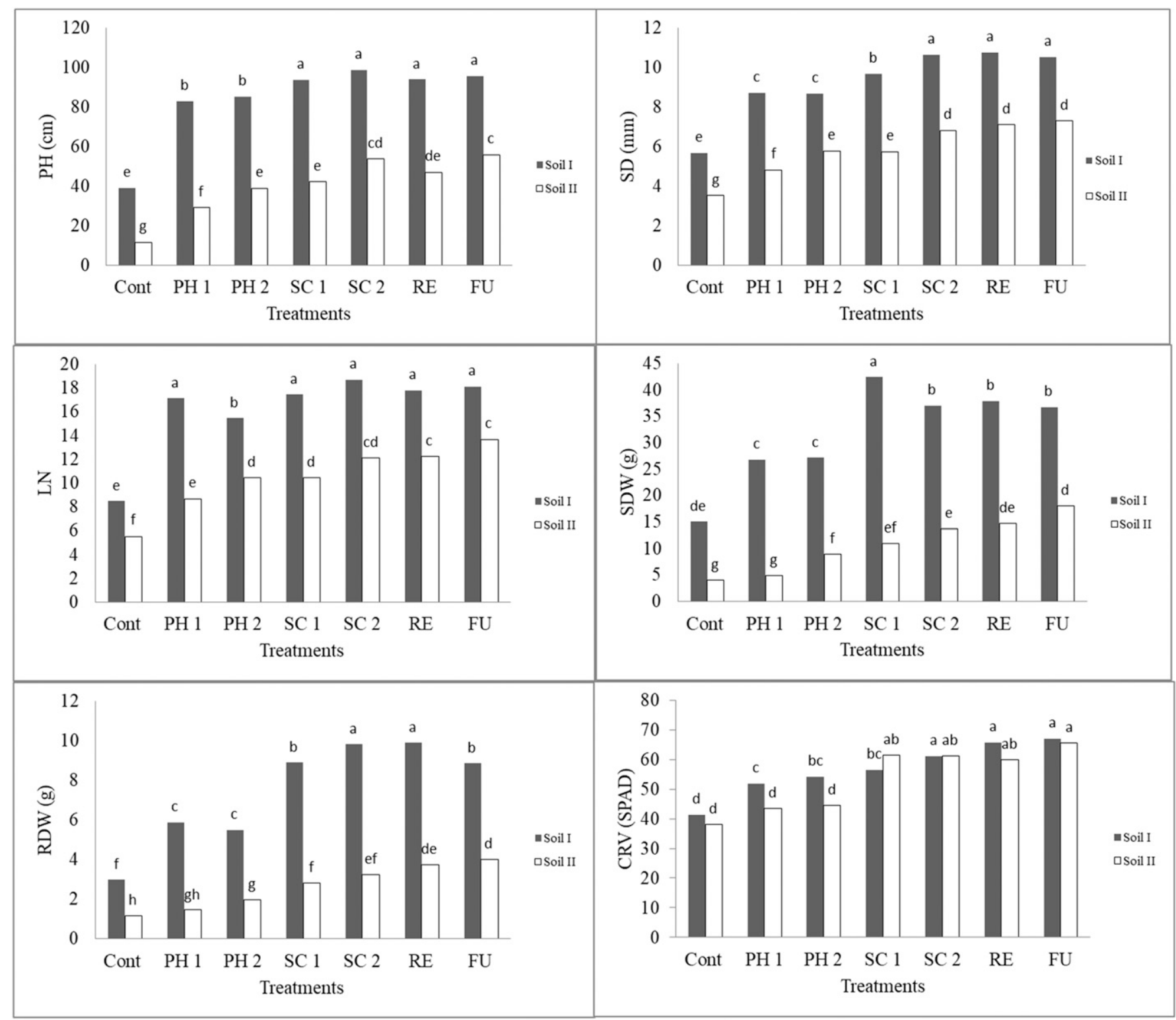

Fig. 1. Effects of biostimulant treatments (Table 2) on plant height (PH), stem diameter (SD), leaf number (LN), shoot dry weight (SDW), root dry weight (RDW), and chlorophyll reading value (CRV) of cherry tomatoes grown in two different soils (Table 1). Bars with the same letter are not significantly different at $P<$ 0.05 . 


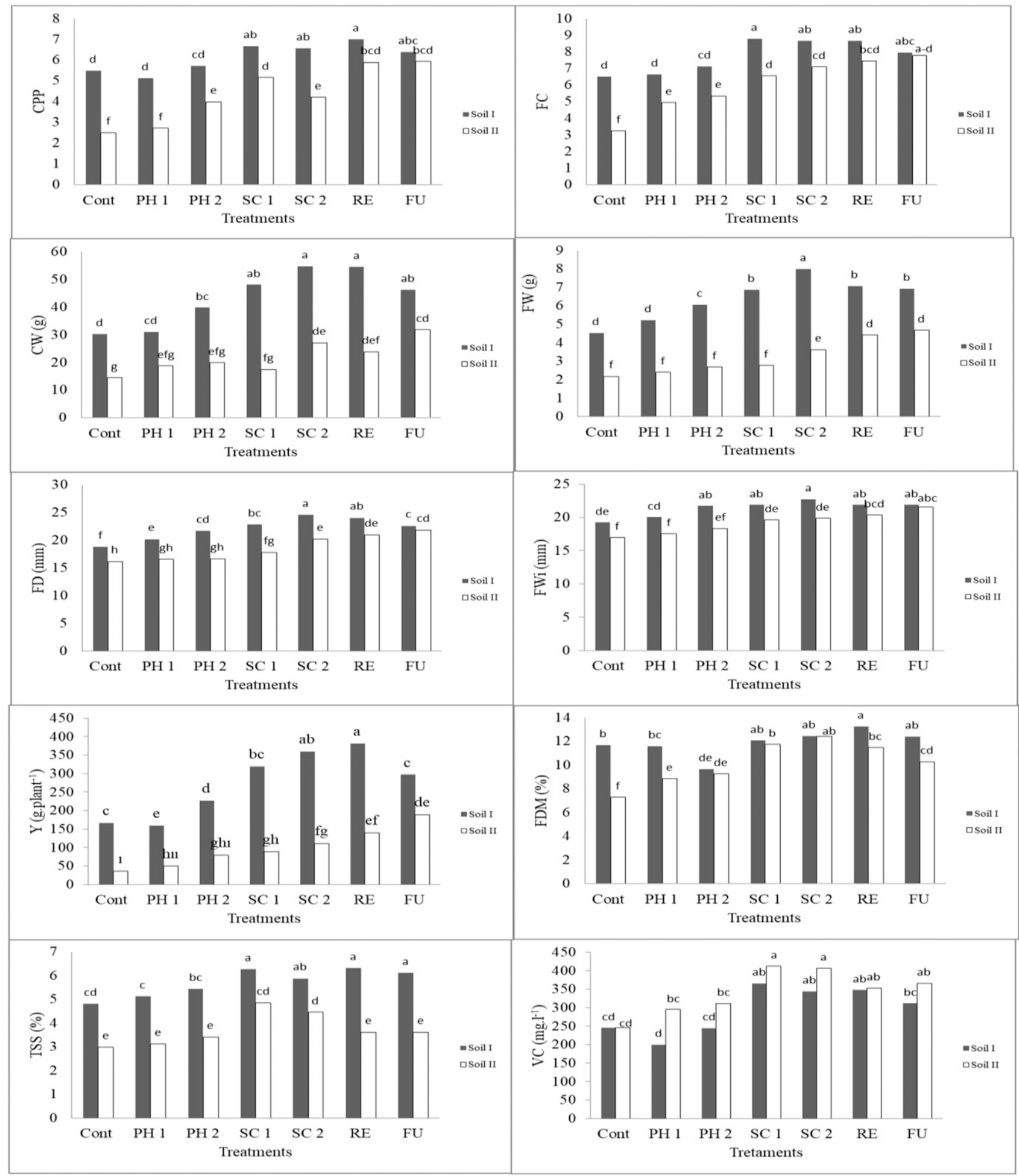

Fig. 2. Effects of biostimulant treatments (Table 2) on cluster per plant (CPP), fruit per cluster (FC), cluster weight (CW), fruit weight (FW), fruit diameter (FD), fruit width (FWi), yield (Y), fruit dry matter (FDM), total soluble solid (TSS), and vitamin C (VC) content of cherry tomatoes grown in two different soils (Table 1). Bars with the same letter are not significantly different at $P<0.05$.

However, as a result of the uncontrolled and excessive use of synthetic pesticides and fertilizers, the accumulation of toxic substances in soil has increased, resulting in soil degradation and environmental pollution. Because soil is not a renewable resource, the protection and regeneration of soil are of great importance for attaining a sustainable future. Therefore, the use of biofertilizers and biostimulants, which increase the soil fertility, has gained importance. In this study, the effects of the single and combined use of biostimulants (high-purity FA and PGPR) on the growth, yield, and quality of cherry tomatoes grown in soils with different characteristics (soil I: fertile; soil II: low organic matter content, high $\mathrm{CaCO}_{3}$ content, and high salinity) were investigated. Although all plant biostimulants improved the plant growth and yield under both soil conditions, the optimum results varied depending on the 


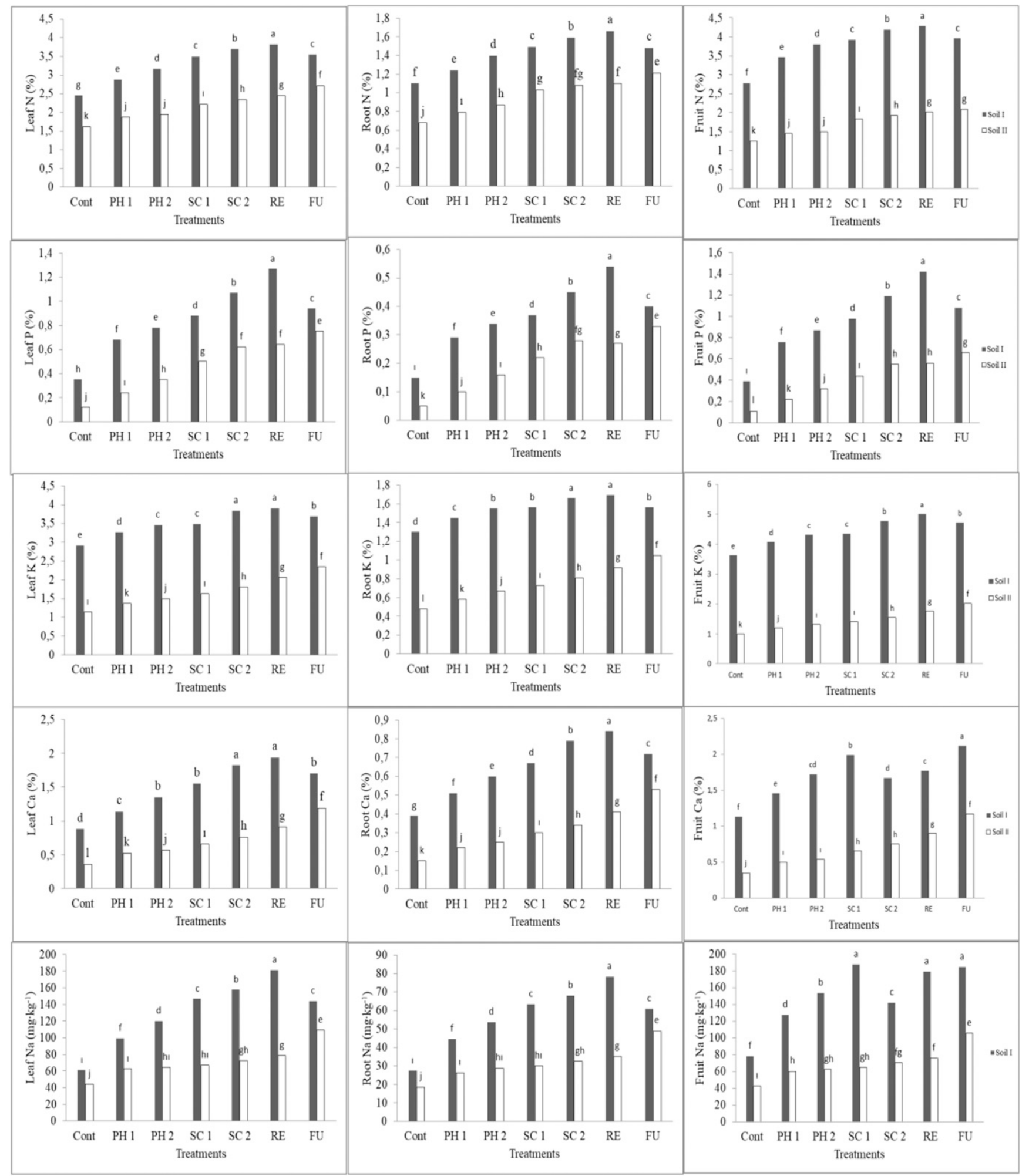

Fig. 3. Effects of biostimulant treatments (Table 2) on N, P, K, Ca, and Na contents of leaves, roots, and fruit of cherry tomatoes grown in two different soils (Table 1). Bars with the same letter are not significantly different at $P<0.05$.

biostimulant used in each soil condition. Biostimulant applications improved the plant growth, yield, dry matter, and TSS in both soil types. Plant biostimulants increased the PH, SD, LN, SPAD, SDW, and RDW by $59 \%$ (FU), 47\% (RE), 54\% (SC2), 38\% (FU), 60\% (RE), and $70 \%(\mathrm{RE})$ in soil I, and by $79 \%$ (FU), 50\% (RE), 60\% (FU), 42\% (FU), 78\%
(FU), and $72 \%$ (FU) in soil II, respectively, compared with the control. This indicated that the FU application had the most effectiveness on all measured factors in soil II, and that RE application had the most effectiveness on all measures in soil I.

The increases in DM, VC contents, TSS, FWi, FD, FW, CW, CPP, FC, and Y per plant under all applications were $12 \%(\mathrm{RE}), 33 \%$ (SC1), 29\% (SC1), 15\% (SC2), 23\% (SC2), $43 \%$ (SC2), 45\% (SC2), 21\% (RE), 26\% (SC1), and $56 \%(\mathrm{RE})$ in soil I, and $41 \%$ (SC2), 40\% (SC1), 38\% (SC1), 21\% (FU), 26\% (FU), 53\% (FU), 54\% (FU), 58\% (FU), $58 \%(\mathrm{FU})$, and $81 \%$ (FU) in soil II, respectively, compared with the control. In both 


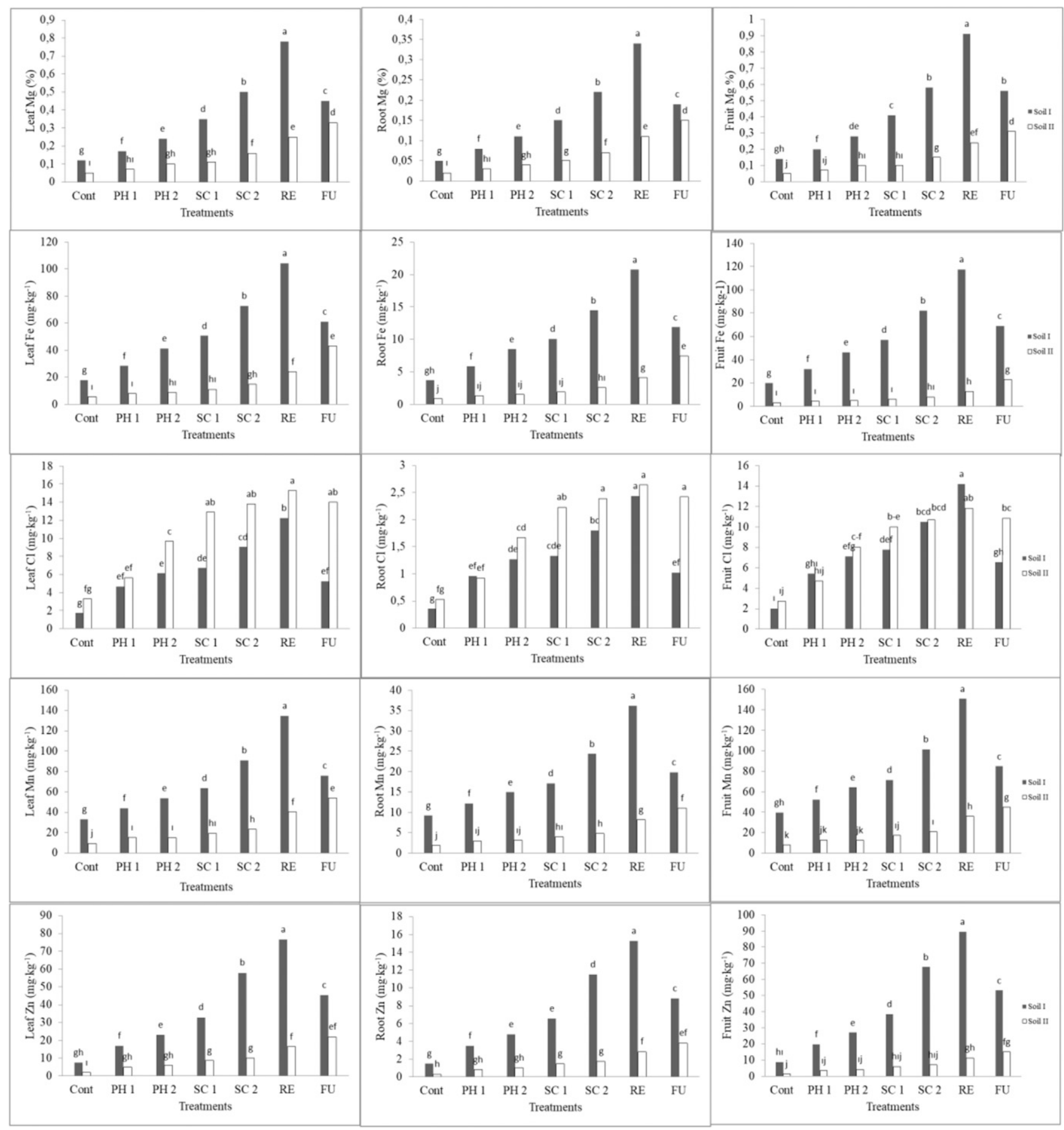

Fig. 4. Effects of biostimulant treatments (Table 2) on $\mathrm{Mg}, \mathrm{Fe}, \mathrm{Cl}, \mathrm{Mn}$, and $\mathrm{Zn}$ contents of leaves, roots, and fruit of cherry tomatoes grown in two different soils (Table 1). Bars with the same letter are not significantly different at $P<0.05$.

soils, SC performed better than $\mathrm{PH}$, thus indicating the positive impact of PGPR in the formulation. However, FU was the most effective treatment in terms of yield, fruit size, and cluster size under stressed soil conditions (soil II). This finding may be explained by the ability of FA to lower the $\mathrm{pH}$ of soil II and improve the nutrient uptake of tomatoes.

Because neutral or slightly acidic $\mathrm{pH}$ is required for tomato growth, the FU treatment performed better in stressed soil conditions. Abdellatif et al. (2017) showed that HA treatments significantly improved plant growth, the number of flowers per cluster, and the general number of flowers per plant compared with the control. Similarly, Suh et al. (2014) found that FA application increased the yield, plant height, fresh weight, and dry weight of tomato plants. Similarly, Suh et al. (2014) found that FA treatments $\left(0.8\right.$ and $\left.1.1 \mathrm{~g} \cdot \mathrm{L}^{-1}\right)$ increased the fruit number and yield of medium and large fruits of tomato. Adani et al. (1998) found that HA applications for tomato significantly increased the plant growth, root growth, fresh weight, and dry weight. Lua and Böhme
(2001) pointed out that HA had an important effect on the root growth and shoot growth of tomato in a hydroponic system. The use of PGPR and HA as foliar and seed applications for peanut increased the dry weight and yield of peanut (El-Syed et al., 2017). However, our results showed that in soils with a high $\mathrm{CaCO}_{3}$ content and high $\mathrm{pH}, \mathrm{HA}$ and/or PGPR were not as effective as FA.

Applications more effectively improved plant growth, fruit quality, and yield parameters of plants in soil II compared to plants in soil I. The positive effects of biostimulants may result 


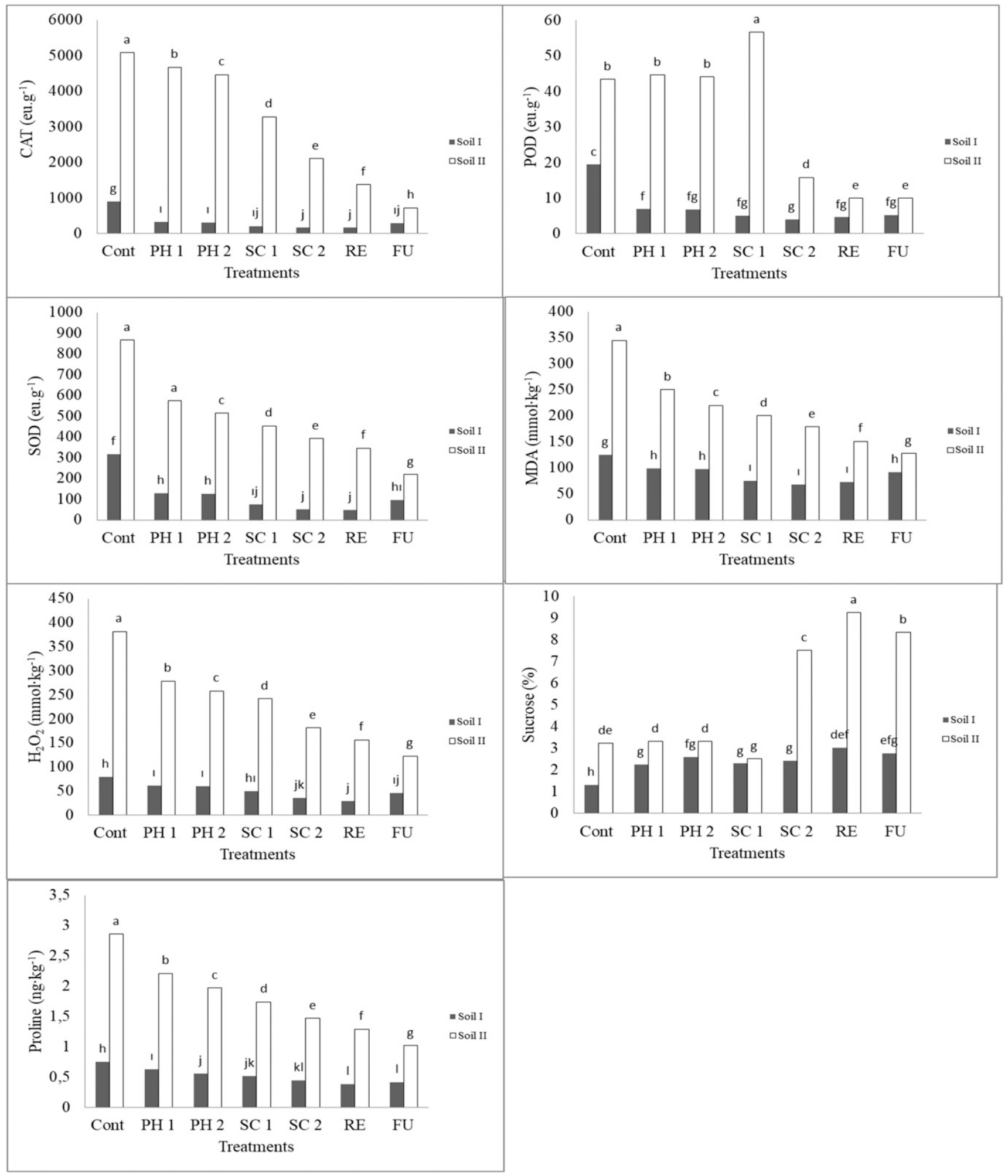

Fig. 5. Effects of biostimulant treatments (Table 2) on the activity of catalase (CAT), peroxide (POD), and superoxide dismutase (SOD) and the contents of malondialdehyde (MDA), hydrogen peroxide $\left(\mathrm{H}_{2} \mathrm{O}_{2}\right)$, proline, and sucrose of leaves, roots, and fruit of cherry tomatoes grown in two different soils (Table 1). Bars with the same letter are not significantly different at $P<0.05$.

from the increased plant tolerance to stressful conditions. Similarly, in a study that examined the effects of HA applications on tomatoes grown under temperature stress, it was determined that HA had a positive effect on plant growth and productivity, yield parameters, yield, and flowering (Abdellatif et al., 2017).
In this study, the positive effects of the applications, especially in soil II, resulted in increased plant growth due to the increase in the nutrient availability and antioxidant enzyme activity in the plant. RE and FU were the most effective applications for mineral content (leaf, root, and fruit) in soil I and in soil II, respectively. $\mathrm{N}, \mathrm{P}, \mathrm{K}, \mathrm{Ca}, \mathrm{Mg}, \mathrm{Mn}, \mathrm{Na}$, $\mathrm{Zn}, \mathrm{Fe}$, and $\mathrm{Cl}$ contents (leaf, root, and fruit) were increased by $23 \%$ to $90 \%$ compared with the control in soil I, whereas the increases in mineral contents ranged from 40 to $92 \%$ in soil II. Similarly, Adani et al. (1998) stated that HA applications enhanced the 
uptake of minerals such as $\mathrm{N}, \mathrm{P}, \mathrm{Fe}$, and $\mathrm{Cu}$ in tomato. Moreover, Lua and Böhme (2001) showed that the nutrient contents (such as $\mathrm{Ca}$ and $\mathrm{K}$ ) of the leaf and fruit of tomato increased with the HA application. However, Turkmen et al. (2004) found that although application doses of 100 to $200 \mathrm{mg} \cdot \mathrm{kg}^{-1}$ increased the $\mathrm{N}, \mathrm{Ca}$, and $\mathrm{S}$ contents in the stem and the $\mathrm{N}$ and $\mathrm{K}$ contents in the root, very high concentrations of HA resulted in decreased nutrient contents. With FA applications, the contents of $\mathrm{P}$ and $\mathrm{Ca}$ of tomato were increased (Suh et al., 2014). Humic substances were found to have similar effects on hormones such as auxin, cytokine, and abscisic acid; therefore, they stimulate the intake of N, P, K, $\mathrm{Fe}, \mathrm{Zn}, \mathrm{Cu}$, and $\mathrm{Mn}$ by enhancing root growth (Mayhew 2004). Moreover, humic substances stimulate $\mathrm{H}^{+}$-ATPase activity and support secondary ion transporters, which encourage the nutrient intake (Canellas et al., 2015).

In soil II, the CAT, POD, and SOD activity and $\mathrm{H}_{2} \mathrm{O}_{2}$, MDA, proline, and sucrose contents of plant were higher than those in soil I conditions. Also, the CAT, POD, and SOD activity and $\mathrm{H}_{2} \mathrm{O}_{2}$, MDA, and proline contents decreased in soil I and soil II with treatments compared with the control, but the POD activity was higher with the SC1 application in soil II. The sucrose content particularly increased with the RE treatment. In stressful environments, applications of biostimulants were reported to increase the plant tolerance by increasing nutrient assimilation and affecting the enzyme activity. Parandian and Samavat (2012) showed that HA and FA applications increased the anthocyanin content, $\alpha$-amylase content, and soluble sugar amount in lilium. Similarly, FA increases the antioxidant capacity of plants. Aminifard et al. (2012) indicated that fruit antioxidant activity, total phenolic content, carbohydrate content, carotenoid content, and capsaicin content were influenced by FA in pepper. PGPR inoculation and the addition of HA for peanuts increased the mineral contents $(\mathrm{N}, \mathrm{P}$, and K) of the shoot (El-Syed et al., 2017). Biostimulator substances provide tolerance to abiotic stress in plants by initiating various molecular processes in plant cells. A study of pepper indicated that HA could reduce the negative effects of salt stress by improving the soil properties, plant growth, and antioxidant capacity (Akladious and Mohamed, 2018). It was determined that humic substances applied to soybeans grown under water stress had a positive effect on plant growth by providing micronutrient uptake (Prado et al., 2016). Humic substances act on different molecular, biochemical, and physiological processes through genetic, post-transcriptional, and posttranslational changes in cells (Shah et al., 2018). When all data were evaluated together, the RE treatment was the most efficient application, whereas the FU treatment had the most effectiveness in soil II.

\section{Conclusion}

In this study, the positive effects of the biostimulant applications, especially in the stressed soil, resulted in increased plant growth by increasing the nutrient availability and antioxidant enzyme activity in plants. Treatments used as a biostimulant in this study have positive effects on plant growth, fruit quality, mineral content, antioxidant enzyme activity, and yield of cherry tomato. The recent use of environmentally friendly production systems in agricultural production has led to the use of inputs that are not harmful to soil fauna and flora. Applications used in this study had positive effects on the growth of cherry tomato, which can prevent or reduce the detrimental soil factors such as excessive fertilizer use. Therefore, these biostimulants might be good candidates for cherry tomato cultivation in problematic soil areas, especially those with stress conditions.

\section{Literature Cited}

Abdellatif, I.M.Y., Y.Y. Abdel-Ati, Y.T. AbdelMageed, and M.A.M. Hassan. 2017. The effect of humic acid on growth and productivity of tomato plants under heat stress. J. Hort. Res. 25(2):59-66.

Adani, F., P. Genevini, P. Zaccheo, and G. Zocchi. 1998. The effect of commercial humic acid on tomato plant growth and mineral nutrition. $\mathrm{J}$. Plant Nutr. 21(3):561-575.

Agarwal, S. and V. Pandey. 2004. Antioxidant enzyme response to $\mathrm{NaCl}$ stress in Cassia angustifolia. Biol. Plant. 48(4):555-560.

Akinci, S. 2017. The effects of humic acids on plant growth and nutrients uptake under stress I: Salinity. Marmara J. Pure Appl. Sci. 29(4): 134-143.

Akladious, S.A. and H.I. Mohamed. 2018. Ameliorative effects of calcium nitrate and humic acid on the growth, yield component and biochemical attribute of pepper (Capsicum annuum) plants grown under salt stress. Scientia Hort. 236:244-250.

Aminifard, M.H., H. Aroiee, H. Nemati, M. Azizi, and H.Z. Jaafar. 2012. Fulvic acid affects pepper antioxidant activity and fruit quality. Afr. J. Biotechnol. 11(68):13179-13185.

Angelini, R., F. Manes, and R. Federico. 1990 Spatial A functional correlation between daimine-oxidase and peroxidase activities and their dependence upon defilation and wounding in chick-pea. Planta 182:89-96.

Battacharyya, D., M.Z. Babgohari, P. Rathor, and B. Prithiviraj. 2015. Seaweed extracts as biostimulants in horticulture. Scientia Hort. 30(196): 39-48.

Bhattacharyya, P.N. and D.K. Jha. 2012. Plant growth-promoting rhizobacteria (PGPR): Emergence in agriculture. World J. Microbiol. Biotechnol. 28(4):1327-1350.

Bradáčová, K., N.F. Weber, N. Morad-Talab, M Asim, M. Imran, and M. Weinmann. 2016. Micronutrients $(\mathrm{Zn} / \mathrm{Mn})$, seaweed extracts, and plant growth-promoting bacteria as cold-stress protectants in maize. Chem. Biol. Technol. Agr. 3(1):19, doi: 10.1186/s40538-016-0069-1.

Bray, E.A., J. Bailey-Serres, E. Weretilnyk, B. Buchannan, and R. Jones. 2000. Responses to abiotic stresses, p. 149-158. In: W. Gruissem and R. Jones (eds.). American Society of Plant Physiologists, Rockville, MD.

Bremner, J.M. 1996. Nitrogen-total, p. 1085 1122. In: D.L. Sparks (ed.). Methods of soil analysis. Part III. Chemical methods. 2nd ed. Soil Science Society of America, Madison, WI.

Canellas, L.P., F.L. Olivares, N.O. Aguiar, D.L. Jones, A. Nebbioso, P. Mazzei, and A. Piccolo.
2015. Humic and fulvic acids as biostimulants in horticulture. Scientia Hort. 196:15-27.

Chen, Y. and T. Aviad. 1990. Effects of humic substances on plant growth 1, p. 161-186. In: P. MacCarthy, C.E. Clapp, R.L. Malcolm, and P.R. Bloom (eds.). Humic substances in soil and crop sciences: Selected readings. American Society of Agronomy and Soil Science Society of America, Madison, WI. doi: 10.2136/1990. humicsubstances.c7.

Cimrin, K.M., O. Turkmen, M. Turan, and B. Tuncer. 2010. Phosphorus and humic acid application alleviate salinity stress of pepper seedling. Afr. J. Biotechnol. 9(36):5845-5851.

Colla, G., S. Nardi, M. Cardarelli, A. Ertani, L. Lucini, and R. Canaguier. 2015. Protein hydrolysates as biostimulants in horticulture. Scientia Hort. 30(196):28-38.

Ekinci, M., M. Turan, E. Yildirim, A. Gunes, R. Kotan, and A. Dursun. 2014. Effect of plant growth promoting rhizobacteria on growth, nutrient, organic acid, amino acid and hormone content of cauliflower (Brassica oleracea L. var. botrytis) transplants. Acta Sci. Pol. Hortorum Cultus 13(6):71-85.

El-Syed, F.R., A.G. Hoda, and M.Y. Yassen. 2017. Growth, nodulation, yield and mineral tissue content of peanut in response to foliar and coating application of humic acid and plant growth-promoting rhizobacteria. J. Environ. Stud. 6(E2):195-202

Glick, B.R. 1995. The enhancement of plant growth by free living bacteria. Can. J. Microbiol. 41(2):109-114.

Gong, Y., P.M. Toivonen, O.L. Lau, and P.A. Wiersma. 2001. Antioxidant system level in 'Braeburn' apple is related to its browning disorder. Bot. Bul. Acad. Sin. 42:259-264.

Gómez-Merino, F.C. and L.I. Trejo-Téllez. 2015. Biostimulant activity of phosphite in horticulture. Scientia Hort. 196:82-90.

Kloepper, J.W., R. Lifshitz, and R.M. Zablotowicz. 1989. Free-living bacterial inocula for enhancing crop productivity. Trends Biotechnol. 7(2):39-43.

Liu, S., Y. Dong, L. Xu, and J. Kong. 2014. Effects of foliar applications of nitric oxide and salicylic acid on salt-induced changes in photosynthesis and antioxidative metabolism of cotton seedlings. Plant Growth Regulat. 73:67-78.

Lua, H.T. and M. Böhme. 2001. Influence of humic acid on the growth of tomato in hydroponic systems. Proc. Int. Symp. on Growing media and Hydroponics. Acta Hort. 548:451-458.

MacCarthy, P. 2001. The Principles of humic substances. Soil Sci. 166(11):738-751.

Man, D., Y.X. Bao, L.B. Han, and X. Zhang. 2011. Drought tolerance associated with proline and hormone metabolism in two tall fescue cultivars. HortScience 46:1027-1032.

Mayhew, L. 2004. Humic substances in biological agriculture. RevAcres USA 34(1-2):80-88

Maynard, D.N. and G.J. Hochmuth. 2007. Knott's handbook for vegetable growers. 5th ed. John Wiley Sons, New York

Mertens, D. 2005a. Official method 922.02. Preparation of plant laboratory samples, p. 1-2. In: W. Horwitz and G.W. Latimer (eds.). Official methods of analysis. 18th ed. Association of Official Agricultural Chemists-International, Gaitherburg, MD

Mertens, D. 2005b. Official method 922.02. Preparation of plant laboratory samples, p. 3-4. In: W. Horwitz and G.W. Latimer (eds.). Official methods of analysis. 18th ed. Association of Official Agricultural Chemists-International, Gaithersburg, MD. 
Mora, V., M. Olaetxea, E. Bacaicoa, R. Baigorri, M. Fuentes, A.M. Zamarreño, and J.M. GarciaMina. 2014. Abiotic stress tolerance in plants: Exploring the role of nitric oxide and humic substances, p. 243-264. In: M. Khan, M. Mobin, F. Mohammad, and F. Corpas (eds.). Nitric oxide in plants: Metabolism and role in stress physiology. Springer, Basel, Switzerland.

Nardi, S., D. Pizzeghello, A. Muscolo, and A. Vianello. 2002. Physiological effects of humic substances on higher plants. Soil Biol. Biochem. 34(11):1527-1536.

Parandian, F. and S. Samavat. 2012. Effects of fulvic and humic acids on anthocyanin, soluble sugar, amylase enzyme and some micronurient elements in lilium. Intl. Res. J. Appl. Basic Sci. 3(5):924-929.

Pettit, R.E. 2008. Organic matter, humus, humate, humic acid, fulvic acid and humin: their importance in soil fertility and plant health. CTI Research, 1-17. <https://humates.com/pdf/ ORGANICMATTERPettit.pdf $>$.

Pichyangkura, R. and S. Chadchawan. 2015. Biostimulant activity of chitosan in horticulture. Scientia Hort. 196:49-65.

Posmyk, M.M. and K. Szafrańska. 2016. Biostimulators: A new trend towards solving an old problem. Front. Plant Sci. 7:748, doi: 10.3389/ fpls.2016.00748.

Prado, M.R.V., O.L.D.S. Weber, M.F.D. Moraes, C.L.R.D. Santos, M. Santos Tunes, and F.T. Ramos. 2016. Humic substances on soybeans grown under water stress. Commun. Soil Sci. Plant Anal. 47(21):2405-2413.

Ruzzi, M. and R. Aroca. 2015. Plant growthpromoting rhizobacteria act as biostimulants in horticulture. Scientia Hort. 30(196):124-134.

Saharan, B.S. and V. Nehra. 2011. Plant growth promoting rhizobacteria: a critical review. Life Sci. Medicine Res. 21(1):1-30.

Sahin, U., M. Ekinci, M.F. Kiziloglu, E. Yildirim, M. Turan, R. Kotan, and S. Ors. 2015. Ameliorative effects of plant growth promoting bacteria on water-yield relationships, growth, and nutrient uptake of lettuce plants under different irrigation levels. HortScience 50(9): 1379-1386, doi: 10.21273/HORTSCI.50.9. 1379.

Sahin, U., M. Ekinci, S. Ors, M. Turan, S. Yildiz, and E. Yildirim. 2018. Effects of individual and combined effects of salinity and drough on physiological, nutritional and biochemical properties of cabbage (Brassica oleracea var. capitata). Scientia Hort. 240:196-204, doi: 10.1016/j.scienta.2018.06.016.

Savvas, D. and G. Ntatsi. 2015. Biostimulant activity of silicon in horticulture. Scientia Hort. 30(196):66-81.

Shah, Z.H., H.M. Rehman, T. Akhtar, H. Alsamadany, B.T. Hamooh, T. Mujtaba, I. Daur, Y.A. Zahrani, H.A.S. Alzahrani, S. Ali, S.H. Yang, and G. Chung. 2018. Humic substances: Determining potential molecular regulatory processes in plants. Front. Plant Sci. 9:263, doi: 10.3389/fpls.2018.00263.

Shams, M., E. Yildirim, M. Ekinci, M. Turan, A. Dursun, F. Parlakova, and R. Kul. 2016. Exogenously applied glycine betaine regulates some chemical characteristics and antioxidative defence systems in lettuce under salt stress. Hort. Environ. Biotechnol. 57(3):225-231.

Sharma, H.S., C. Fleming, C. Selby, J.R. Rao, and T. Martin. 2014. Plant biostimulants: a review on the processing of macroalgae and use of extracts for crop management to reduce abiotic and biotic stresses. J. Appl. Phycol. 26:465-490.

Suh, H.Y., K.S. Yoo, and S.G. Suh. 2014. Effect of foliar application of fulvic acid on plant growth and fruit quality of tomato (Lycopersicon esculentum L.). Hort. Environ. Biotechnol. 55(6):455-461.

Thao, H.T.B. and T. Yamakawa. 2009. Phosphite (phosphorous acid): Fungicide, fertilizer or biostimulator? Soil Sci. Plant Nutr. 55(2):228-234.
Turan, M., M. Ekinci, E. Yildırım, A. Gunes, K. Karagoz, R. Kotan, and A. Dursun. 2014. Plant growth-promoting rhizobacteria improved growth, nutrient and hormone content of cabbage (Brassica oleracea) seedlings. Turk. J. Agr. For. 38(3):327-333.

Turkmen, O., A. Dursun, M. Turan, and E. Ceknas. 2004. Calcium and humic acid affect seed germination, growth, and nutrient content of tomato (Lycopersicon esculentum L.) seedlings under saline soil conditions. Acta Agr. Scand. B Soil Plant Sci. 54(3):168-174.

Van Oosten, M.J., O. Pepe, S. De Pascale, S. Silletti, and A. Maggio. 2017. The role of biostimulants and bioeffectors as alleviators of abiotic stress in crop plants. Chem. Biol. Technol. Agr. 4(1):5, doi: 10.1186/s40538-017-0089-5.

Wu, X., W. Zhu, H. Zhang, H. Ding, and H.J. Zhang. 2011. Exogenous nitric oxide protects against salt-induced oxidative stress in the leaves from two genotypes of tomato ( $\mathrm{Lyco}$ persicom esculentum Mill.). Acta Physiol. Plant. 33:1199-1209.

Yildirim, E. 2007. Foliar and soil fertilization of humic acid affect productivity and quality of tomato. Acta Agr. Scand. B Soil Plant Sci. 57(2):182-186.

Yildirim, E., M. Turan, M. Ekinci, A. Dursun, A. Gunes, and M.F. Donmez. 2015. Growth and mineral content of cabbage seedlings in response to nitrogen fixing rhizobacteria treatment. Rom. Biotechnol. Lett. 20(6):10929-10939.

Yordanova, R.Y., K.N. Christov, and L.P. Popova. 2004. Antioxidative enzymes in barley plants subjected to soil flooding. Environ. Expt. Bot. 51:93-101.

Zhang, X. and E.H. Ervin. 2008. Impact of seaweed extract-based cytokinins and zeatin riboside on creeping bentgrass heat tolerance. Crop Sci. 48(1):364-370.

Zhu, J.K. 2016. Abiotic stress signaling and responses in plants. Cell 167(2):313-324. 